\title{
CONSERVATION BUFFERS DESIGN GUIDELINES FOR BUFFERS, CORRIDORS, AND GREENWAYS
}

\author{
Straight, Richard ${ }^{1}$ and Bentrup, Gary ${ }^{2}$
}

\section{SUMMARY}

A large body of scientific knowledge exists to help guide the planning and designing of buffers. Unfortunately, this information is widely dispersed throughout the vast repositories of research literature and is not easily accessible or usable for most planners. The purpose of this publication is to provide a synthesis of this diverse knowledge base into distilled, easy-to-understand design guidelines.

Over 80 illustrated design guidelines for conservation buffers are synthesized and developed from a review of over 1,400 research publications. Each guideline describes a specific way that a vegetative buffer can be applied to protect soil, improve air and water quality, enhance fish and wildlife habitat, produce economic products, provide recreation opportunities, or beautify the landscape.

These science-based guidelines are presented as easy-to-understand rules-ofthumb for facilitating the planning and designing of conservation buffers in rural and urban landscapes.

The guide also provides a logical and easy to use process for determining the buffer design features needed to create multi-functional conservation buffers. The online version of the guide includes the reference publication list as well as other buffer design resources www.bufferguidelines.net.

Keywords: Buffer, conservation planning, conservation practice, corridor, filter strip, greenway, riparian, streamside management zone, windbreak.

1 US Department of Agriculture, National Agroforestry Center, United States, rstraight@fs.fed.us 2 US Department of Agriculture, National Agroforestry Center, United States, gbentrup@fs.fed.us 


\section{ZONAS DE AMORTIGUAMIENTO PARA CONSERVACIÓN LINEAMIENTOS PARA DISEÑO DE ZONAS DE AMORTIGUAMIENTO, CORREDORES Y VÍAS VERDES}

\section{RESUMEN}

Existe un cuantioso acervo de conocimientos científicos para guiar la planeación y el diseño de zonas de amortiguamiento. Infortunadamente, esta información está ampliamente dispersa a través de los vastos repositorios de literatura de investigación y no es fácilmente accesible o utilizable para la mayoría de planificadores. El objetivo de esta publicación es brindar una síntesis de esta diversa base de conocimientos en lineamientos de diseño condensados y fáciles de comprender.

A partir de la revisión de más de 1400 publicaciones de investigación, se sintetizan, formulan e ilustran más de 80 lineamientos de diseño para zonas de amortiguamiento para conservación. Cada lineamiento describe una manera específica en que una zona de amortiguamiento vegetativa se puede aplicar para proteger el suelo, mejorar la calidad del aire y del agua, mejorar el hábitat acuático y de la flora y fauna silvestre, generar productos económicos, brindar oportunidades recreativas o embellecer el paisaje.

La exposición de estos lineamientos, con base científica, se desarrolla en forma de reglas empíricas fáciles de entender a fin de facilitar la planificación y el diseño de zonas de amortiguamiento para conservación en paisajes rurales y urbanos.

La guía también proporciona un proceso lógico y de uso fácil para determinar las características de diseño de las zonas de amortiguamiento necesarias para crear áreas de amortiguamiento y conservación multifuncionales.

La versión de esta guía en el Internet incluye una lista de referencias bibliográficas de la publicación, así como también otros recursos para diseñar zonas de amortiguamiento: www.bufferguidelines.net.

Palabras clave: Zona de amortiguamiento, planificación de conservación, práctica de conservación, corredor, franja de filtro, vía verde, ripícola, zona de gestión de márgenes ribereñas, cortinas cortavientos. 


\section{INTRODUCTION}

Conservation buffers are strips or bands of vegetation placed in the landscape to improve ecological processes that have been impaired as a result of human land uses and management. These buffers also provide a variety of goods and services on site as well as the larger landscape and community, sometimes referred to as environmental services. Conservation buffers are called by many names depending on the location, cultural context, and professional discipline; wildlife corridors, greenways, windbreaks, hedgerows, trap strips, and filter strips are a few of the common names.

Conservation buffers are not inherently agroforestry practices, indeed most conservation buffers have no relationship to agroforestry systems and practices. Historically, conservation buffers have been designed to serve one purpose, trap sediment, reduce wind speed, slow water movement, others. All of which are intended to ameliorate the detrimental impacts to the environment, often water quality, created by large scale, single purpose land use management. Agroforestry systems on the other hand are designed to serve many functions including modification of temperature and hydrology, diversity of crops and products to increase economic diversity and stability through intensive management that takes advantage of the interactions between perennial and annual crops.

However, many of the characteristics of conservation buffers that make them effective are what make agroforestry systems productive and sustainable. Conservation buffers and agroforestry systems both introduce permanent and perennial vegetation into what are often annual cropping systems. Both also introduce plant species and structure diversity into the landscape of monoculture or at least minimally diverse cropping systems. These characteristics also influence micro-climate and add resiliency to the land use system.

Conservation buffers are designed and implemented to address many issues and to achieve many different land manager and societal objectives. The many buffer objectives can be grouped into seven major issues: Water quality, biodiversity, productive soils, economic opportunities, protection and safety, aesthetics and visual, and outdoor recreation. The design objectives of buffers are achieved by enhancing certain landscape functions. Most buffers will perform more than one function, even if designed with only one function in mind. This means that buffers may also function in ways that may not be desirable in every situation. These landscape functions are greatly influenced by the landscape position, the structure of the buffer created by the size, shape, and structure of the vegetation, and the juxtaposition of the buffer to other buffers and land uses.

It doesn't take much consideration to realize that designing conservation buffers and agroforestry practices to meet more than just a few objectives can become complicated and even daunting to the land manager or resource conservation professional. In this day and age of increased awareness of climate change, necessity of increased food production, clean air and water, expectations of wildlife protection, safe food, and energy efficiency the expectations of food, fiber, and energy production continue to increase. There is no shortage of agencies, organizations, and universities searching for solutions to these many issues and problems. Consequently a large body of scientific knowledge 
exists to help guide the planning and designing of buffers. But research, often by its very nature, focuses on the effect of changing one element while keeping all else constant. One can see how different the research context is from the land manager's situation in which possibly only one thing can be kept constant while everything else changes in the field. As well, the many diverse objectives of conservation buffers and agroforestry systems lead to relevant research being done within many different areas of discipline and residing in vast repositories of research literature that is not easily accessible or usable for most planners.

\section{OBJECTIVES}

Throwing one's hands into the air in exasperation or burying one's head in the sand are not acceptable responses, the world moves on with or without us. An attempt by the United States Department of Agriculture's National Agroforestry Center to reign in the complex nature of designing conservation buffers to achieve multiple objectives across a multitude of situations resulted in "Conservation Buffers: Design Guidelines for Buffers, Corridors, and Greenways", referred to as the Buffer Guide (Bentrup, 2008).

The purpose of the Buffer Guide is to provide a synthesis of the available and diverse knowledge into distilled, easy-to-understand design guidelines.

\section{METHODS}

An extensive literature review was undertaken across a diverse array of disciplines, journals, and countries in order to accumulate a full compendium of research related to conservation buffers. In all, over 1,400 research articles were determined to have relevant conclusions.

Research results were evaluated and compared to determine the range of buffer design criteria as they relate to buffer function and the degree of confidence of results to achieve buffer objectives. Synthesis of research continued to create specific guidelines organized by thirty-five buffer functions for which research has been undertaken. The information was then organized into a draft Buffer Guidelines field book for field testing.

The draft Buffer Guide field book was presented to a sample of natural resource professionals currently engaged in designing conservation buffers for agricultural producers. Participants were asked to provide comment on the accuracy, convenience, and ease of finding relevant information for designing conservation buffers.

Recommendations focused on three elements of the Buffer Guide:

Graphics to depict each of the guidelines

Organize information according to primary issues of concern

Small enough and resistant to water for use in the field. 


\section{RESULTS}

The Buffer Guide contains over 80 graphically-depicted design guidelines developed from more than 1,400 research articles from disciplines as diverse as agricultural engineering, conservation biology, economics, hydrology, landscape ecology, social sciences, and urban ecology.

The Buffer Guide is not a cookbook for designing conservation buffers. Rather it is a synthesis of the best available science that can be combined as needed to create customized conservation buffers. Some of the guidelines reflect many years of research and are offered with a high level of confidence while other guidelines are based on limited research and reflect a greater degree of extrapolation to generalize them.

There are still many gaps in our understanding of buffers and their ecological and socioeconomic functions and impacts.

The planner must weave these guidelines together with first-hand knowledge of the site, the landscape, and landowner goals to create a design that optimizes benefits and minimizes potential problems.

Consequently, the Buffer Guide should not serve as a sole source for design information, but rather as a means to facilitate and communicate the design process.

\section{Structure of the Buffer Guide}

The Buffer Guide is organized into seven sections, one for each major environmental issue: water quality, biodiversity, productive soils, economic opportunities, protection and safety, aesthetics and visual, and outdoor recreation.

Each section begins with a list of the objectives that can be achieved within the specific issue in question followed by the different buffer functions that are at work to help accomplish the stated objectives.

A matrix is then presented to display the design guidelines that are relevant for each buffer function. This design guidelines matrix is then followed by a similar matrix containing additional design guidelines that may be useful in addressing the primary issue (Figure 1).

The guidelines in this second matrix are numbered according to the section of the Buffer Guide where they can be found. These two matrices allow the planner to determine which guidelines will influence any given buffer function.

This becomes particularly useful when designing buffers to achieve multiple objectives or address multiple issues. Table 1 is a summary of seven issues, 18 objectives, and 35 buffer functions. 
The Buffer Guide also contains an introductory section on how to use the Guide to assist in designing multi-functional buffers as well as a brief glossary of terms at the end.

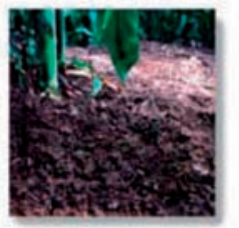

\section{Productive} Soils

\section{Objectives}

- Reduce soil erosion

Increase soil productivity

\section{Buffer functions}

1. Reduce water runoff energy

2. Reduce wind energy

3. Stabilize soil

4. Improve soil quality

5. Remove soil pollutants

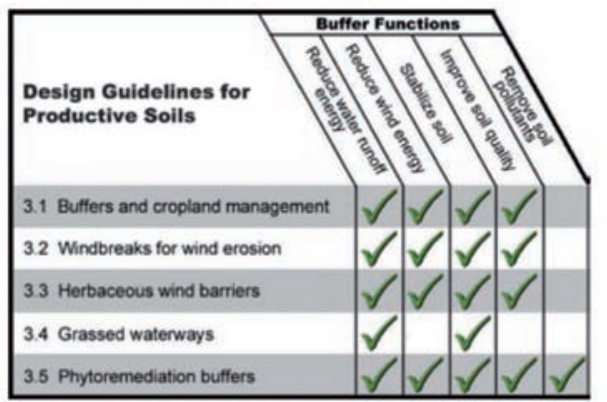




\section{TABLE 1}

\section{BUFFER FUNCTIONS RELATED TO ISSUES AND OBJECTIVES}

\begin{tabular}{|c|c|}
\hline Issues and Objectives & Buffer Functions \\
\hline \multicolumn{2}{|c|}{ Water Quality } \\
\hline Reduce erosion and runoff of sediment, nutrients, & Slow water runoff and enhance infiltration \\
\hline \multirow[t]{2}{*}{ and other potential pollutants } & Trap pollutants in surface runoff \\
\hline & Trap pollutants in subsurface flow \\
\hline \multirow[t]{2}{*}{ Remove pollutants from water runoff and wind } & Stabilize soil \\
\hline & Reduce bank erosion \\
\hline \multicolumn{2}{|c|}{ Biodiversity } \\
\hline & Increase habitat area \\
\hline \multirow[t]{2}{*}{ Enhance terrestrial habitat } & Protect sensitive habitats \\
\hline & Restore connectivity \\
\hline \multirow[t]{2}{*}{ Enhance aquatic habitat } & Increase access to resources \\
\hline & Shade stream to maintain temperature \\
\hline \multicolumn{2}{|c|}{ Productive Soils } \\
\hline & Reduce water runoff energy \\
\hline \multirow[t]{2}{*}{ Reduce soil erosion } & Reduce wind energy \\
\hline & Stabilize soil \\
\hline \multirow[t]{2}{*}{ Increase soil productivity } & Improve soil quality \\
\hline & Remove soil pollutants \\
\hline \multicolumn{2}{|c|}{ Economic Opportunities } \\
\hline & Produce marketable products \\
\hline Provide income sources & Reduce energy consumption \\
\hline Increase economic diversity & Increase property values \\
\hline \multirow[t]{2}{*}{ Increase economic value } & Provide alternative energy sources \\
\hline & Provide ecosystem services \\
\hline \multicolumn{2}{|c|}{ Protection and Safety } \\
\hline Protect form wind or snow & Reduce wind energy \\
\hline Increase biological control of pests & Modify microclimate \\
\hline Protect from flood waters & Enhance habitat for predators of pests \\
\hline \multirow[t]{2}{*}{ Create a safe environment } & Reduce flood water levels and erosion \\
\hline & Reduce hazards \\
\hline \multicolumn{2}{|c|}{ Aesthetics and Visual Quality } \\
\hline & Enhance visual interest \\
\hline Enhance visual quality & Screen undesirable views \\
\hline Control noise levels & Screen undesirable noise \\
\hline \multirow[t]{2}{*}{ Control air pollution } & Filter air pollutants and odors \\
\hline & Separate human activities \\
\hline \multicolumn{2}{|c|}{ Outdoor Recreation } \\
\hline & Increase natural areas \\
\hline \multirow[t]{2}{*}{ Promote nature-based recreation } & Protect natural areas \\
\hline & Protect soil and plant resources \\
\hline \multirow[t]{2}{*}{ Use buffers as recreational trails } & Provide a corridor for movement \\
\hline & Enhance recreational experience \\
\hline
\end{tabular}




\section{How to Use the Guide}

The Buffer Guide is not designed to determine the issues of concern for any given site, watershed or region. The issues of concern and related objectives should be identified with assistance of the land owner or manager, or stakeholder group using an accepted planning process. Mutual acceptance of the primary issues that need to be addressed helps insure the proper implementation and long term maintenance of conservation buffers.

Even though the Buffer Guide can be used in designing conservation buffers that address single issues, it is intended as a tool to assist in designing conservation buffers that accomplish multiple objectives and address multiple social and environmental issues.

The process begins by comparing the agreed upon issues or concerns that the landowner or group wishes to address. Using Table 1 in the Buffer Guide (Table 1) identify the buffer functions that can work to address the issue. Next create a table or matrix with these buffer functions along one axis and the buffer design elements such as width, plant selection, site location and layout, and other subjects along the other axis.

Then, referring to the appropriate resource concern section for each buffer function, review the guideline-function matrices at the beginning of each section and select and record the guidelines that influence the desired buffer functions.

Each resource section also contains an additional design guideline-function matrix that can be used to select and record additional guidelines from other resource sections that may be useful. Review each guideline and begin to enter into the matrix the relevant pertinent information associated with each buffer design characteristic for each objective. (see Table 2 for an example).

In this example, Table 2, the two buffer functions are:

1) Shade stream to maintain water temperature.

2) Bank stabilization.

After reviewing the fourteen buffer guidelines that are most likely to assist in providing the two functions, the appropriate design considerations are summarized for each design consideration.

For this example only site location and layout, height, and length design elements are being detailed along with a summary of the effectiveness that buffers may have in providing the desired function.

As the different guidelines are analyzed and compared, guidelines that are more restrictive may be identified as well as potential conflicts between guidelines that are being considered. It will be useful to then write synthesized design criteria for each buffer design element, Table 3. 
During this final design process the Buffer Guide can be used as a communication tool among the decision makers to finalize the conservation buffer design.

TABLE 2

EXAMPLE TABLE USED TO ORGANIZE GUIDELINES FOR TWO BUFFER FUNCTIONS

\begin{tabular}{|c|c|c|}
\hline \multicolumn{2}{|c|}{ Shade Stream to MaintainTemperature } & \multirow{2}{*}{$\begin{array}{c}\text { Reduce Excessive Bank Erosion } \\
1.1,1.4,1.6,1.17,1.18,1.22,1.24,2.9,2.11\end{array}$} \\
\hline $\begin{array}{l}\text { Guidelines for } \\
\text { consideration }\end{array}$ & $1.4,2.6,3.2,6.5,7.3$ & \\
\hline $\begin{array}{l}\text { Summary of } \\
\text { effectiveness }\end{array}$ & $\begin{array}{l}\text { Buffers can help maintain cooler water } \\
\text { temperatures in small streams if the } \\
\text { vegetation provides adequate shade on } \\
\text { the water surface; removal of riparian } \\
\text { vegetation often results in summer } \\
\text { temperature increases from } 5 \text { to } 11^{\circ} \\
\text { C. Methods and models for calculating } \\
\text { riparian shade and modeling effects } \\
\text { of shade on water temperatures are } \\
\text { available. }\end{array}$ & $\begin{array}{l}\text { Buffers of streambank vegetation can } \\
\text { substantially increase bank stability and } \\
\text { reduce excessive bank erosion compared } \\
\text { to streambanks without vegetation. In some } \\
\text { situations, the forces causing bank erosion } \\
\text { may be greater than the protective capabilities } \\
\text { of vegetation. In addition to these guidelines, } \\
\text { other design resources are available. }\end{array}$ \\
\hline $\begin{array}{l}\text { Landscape } \\
\text { setting }\end{array}$ & $\begin{array}{l}\text { Vegetative shading is more effective } \\
\text { on small streams To moderate } \\
\text { temperatures in a larger stream, buffer } \\
\text { the network of headwater streams } \\
\text { feeding into the larger stream. Buffers } \\
\text { are more effective in watersheds that } \\
\text { have a higher percentage of overall } \\
\text { vegetative cover. }\end{array}$ & $\begin{array}{l}\text { Buffers will be more effective on smaller } \\
\text { streams with low discharge, particularly with } \\
\text { small peak flood events, and along relatively } \\
\text { stable streams. Buffers will be less effective } \\
\text { in watersheds with increasing runoff (e.g., } \\
\text { increasing impervious cover, channelization). }\end{array}$ \\
\hline $\begin{array}{l}\text { Site location and } \\
\text { layout }\end{array}$ & $\begin{array}{l}\text { Vegetative shading is generally more } \\
\text { effectivenearthewater's edgeandalong } \\
\text { west and south streambanks. Shade } \\
\text { appears to moderate temperatures } \\
\text { more effectively in streams with a } \\
\text { higher width to depth ratio. Buffer } \\
\text { shading effectiveness decreases as } \\
\text { stream width increases. Streambank } \\
\text { and hill shade should be incorporated } \\
\text { in the design. }\end{array}$ & $\begin{array}{l}\text { Locate buffers on both sides of stream; } \\
\text { stabilizing just one side can accelerate erosion } \\
\text { on the other side. Streambanks with higher silt/ } \\
\text { clay content may hinder root density, leading to } \\
\text { higher erosion rates. Stream reaches with bank } \\
\text { heights greater than } 1 \mathrm{~m} \text { will be more difficult to } \\
\text { stabilize. Establish vegetation as far down the } \\
\text { base of the bank as possible. }\end{array}$ \\
\hline Height & $\begin{array}{l}\text { Taller vegetation consisting of large } \\
\text { trees will provide more shade. Un- } \\
\text { mowed or un-grazed tall grass buffers } \\
\text { may provide adequate shade on } \\
\text { streams less than } 2.5 \mathrm{~m} \text { wide. }\end{array}$ & $\begin{array}{l}\text { There is limited research on vegetation height } \\
\text { and bank erosion. On high, steep banks, large } \\
\text { trees may increase mass failure by adding weight } \\
\text { to the bank and creating toppling leverage. } \\
\text { Dense shading from tall species can suppress } \\
\text { understory growth leading to unprotected areas } \\
\text { that are susceptible to erosion. }\end{array}$ \\
\hline
\end{tabular}




\section{TABLE 3 \\ EXAMPLE OF TABLE WITH SUMMARIZED GUIDELINES}

\begin{tabular}{|c|c|c|}
\hline \multicolumn{2}{|c|}{ Shade Stream to Maintain Temperature } & Reduce Excessive Bank Erosion \\
\hline Guidelines & $1.4,2.6,3.2,6.5,7.3$ & $1.1,1.4,1.6,1.17,1.18,1.22,1.24,2.9,2.11$ \\
\hline $\begin{array}{l}\text { Summary of } \\
\text { effectiveness }\end{array}$ & $\begin{array}{l}\text { Buffers can help maintain cooler water } \\
\text { temperatures in small streams if the } \\
\text { vegetation provides adequate shade on } \\
\text { the water surface; removal of riparian } \\
\text { vegetation often results in summer } \\
\text { temperature increases from } 5 \text { to } 11^{\circ} \\
\text { C. Methods and models for calculating } \\
\text { riparian shade and modeling effects } \\
\text { of shade on water temperatures are } \\
\text { available. }\end{array}$ & $\begin{array}{l}\text { Buffers of streambank vegetation can substantially } \\
\text { increase bank stability and reduce excessive } \\
\text { bank erosion compared to streambanks without } \\
\text { vegetation. In some situations, the forces causing } \\
\text { bank erosion may be greater than the protective } \\
\text { capabilities of vegetation. In addition to these } \\
\text { guidelines, other design resources are available. }\end{array}$ \\
\hline $\begin{array}{l}\text { Landscape } \\
\text { setting }\end{array}$ & \multicolumn{2}{|c|}{$\begin{array}{l}\text { Buffers will be more effective on smaller streams with low discharge, particularly with small } \\
\text { peak flood events, and along relatively stable streams. }\end{array}$} \\
\hline $\begin{array}{l}\text { Site location } \\
\text { and layout }\end{array}$ & \multicolumn{2}{|c|}{$\begin{array}{l}\text { Vegetative shading is generally more effective near the water's edge and along west and south } \\
\text { streambanks. Shade appears to moderate temperatures more effectively in streams with a } \\
\text { higher width to depth ratio. Buffer shading effectiveness decreases as stream width increases. } \\
\text { Streambank and hill shade should be incorporated in the design. Locate buffers on both sides } \\
\text { of stream; stabilizing just one side can accelerate erosion on the other side. Streambanks with } \\
\text { higher silt/clay content may hinder root density, leading to higher erosion rates. Stream reaches } \\
\text { with bank heights greater than } 1 \mathrm{~m} \text { will be more difficult to stabilize. Establish vegetation as far } \\
\text { down the base of the bank as possible. }\end{array}$} \\
\hline Height & \multicolumn{2}{|c|}{$\begin{array}{l}\text { Taller vegetation consisting of large trees will provide more shade. But avoid large trees in } \\
\text { areas most vulnerable to mass failure. Select and maintain appropriate over-story species } \\
\text { that will not suppress understory growth leading to unprotected areas that are susceptible to } \\
\text { erosion. }\end{array}$} \\
\hline
\end{tabular}

In addition to the experience of the natural resource professional, the landowner, and agency technical and program standards, and local conservation resources, the online version of the Buffer Guide, www.bufferguidelines.net, also provides over 1,400 references for information and review to assist in the design of any conservation buffer. The referenced publications may provide additional design information, including more detailed design criteria for specific geographic regions.

\section{Next Steps}

At the time of this writing, the Buffer Guide has been available and in use for about $1 \frac{1}{2}$ years. Currently under development is a conservation buffer objectives-functionsguidelines matrix that is intended to assist planners in the process of designing multifunctional conservation buffers.

The primary value of the matrix will be as an easy to use reference to determine which of guidelines that are under consideration are more limiting or are in conflict with each other. This will in turn assist in determining which objectives can be mutually achieved or are mutually exclusive. 
A cooperative research project with lowa State University is currently underway to determine how well the Buffer Guide is designed to assist natural resource professionals in designing conservation buffers and if use of the Buffer Guide in the design process creates any efficiencies. An initial survey of a limited number of people and is expected to be the foundation of a more comprehensive study encompassing a larger and more geographically diverse group of participants. Initial results of the study indicate that the Buffer Guide is perceived to be technically sound and useful by both practitioners and outside experts. However, respondents also believe that the Buffer Guide's usability could be improved with training, better marketing particularly of the online resources, and by providing regional or watershed guides to support application in specific parts of the country.

\section{CONCLUSIONS}

Demands and expectations of agricultural and forest land uses are increasing. Society no longer expects only food or wood from these lands, but also clean water, wildlife habitat, carbon sequestration, clean air, and energy production among many others.

Agroforestry systems and practices such as conservation buffers are certainly a part of the solution. Even with increased research on how to design and manage agroforestry systems, agricultural and forest lands it will be impossible to research and answer all the questions for every situation. But the expectations will continue.

This is the role of conservation buffer design guidelines, a synthesis of knowledge, distilled and easy-to-understand, to assist in designing multi-functional conservation buffers.

\section{REFERENCES}

Bentrup, G., 2008. Conservation buffers: design guidelines for buffers, corridors, and greenways. General Technical Report SRS-109. Asheville, NC, USA: Department of Agriculture, Forest Service, Southern Research Station. 110 p. 


\section{LA AGROFORESTERIA UNA ALTERNATIVA PARA LA AGRICULTURA FAMILIAR CAMPESINA. Renato Coda Salgado, Instituto}

de Desarrollo Agropecuario. Chile. rcoda@indap.cl y Alvaro Sotomayor Garreton, Instituto Forestal. Chile. asotomay@infor.cl

\section{RESUMEN}

La agroforestería es una alternativa y oportunidad para que los pequeños productores silvoagropecuarios puedan hacer un uso integral y racional de sus recursos naturales, especialmente el suelo. Además, la agroforestería no solo es una opción para mitigar los procesos erosivos de los suelos, sino que también es una alternativa productiva frente a cultivos tradicionales, que se desarrollan muchas veces en terrenos de aptitud forestal, con rendimientos decrecientes y por ende bajas rentabilidades.

INDAP consciente de la necesidad de generar y desarrollar nuevas alternativas productivas para sus usuarios, en conjunto con INFOR, entre el año 2003 y 2008, llevó a cabo un Programa de Desarrollo Agroforestal, con el propósito de estudiar aquellos sistemas agroforestales que mejor pudieran aplicarse en terrenos de pequeños propietarios, usuarios del Instituto.

El programa contempló la instalación de unidades demostrativas en el secano interior de las regiones del Maule, del Bio Bio y de La Araucanía; al sur de la región de Los Lagos, y en la región de Aysén, a través de las cuales se obtuvieron valiosos antecedentes que permitieron generar alternativas agroforestales, las cuales fueron implementadas posteriormente en terrenos de pequeños agricultores, en una superficie aproximada de 500 ha.

Se presenta en esta propuesta, el modelo de gestión seguido, los resultados obtenidos y una propuesta de Programa Agroforestal para su implementación en Chile.

Palabras clave: Agroforestería, pequeños propietarios

\section{SUMMARY}

Agroforestry is an alternative and opportunity for small forestry and agricultural producers, to make a comprehensive and rational use of natural resources, especially soil. In addition, agroforestry is not only an option to mitigate the erosion of soils, but also a productive alternative compared to traditional crops, which often develop in areas suitable for forestry, with diminishing returns and therefore lower returns

INDAP aware of the need to generate and develop new alternatives for its users, along with INFOR, conducted an Agroforestry Development Program between 2003 and 
2008, in order to study those agroforestry systems which could better be applied in lands of small owners, who are clients of the Institute

The program included the establishment of demonstration units in the dry areas (secano interior) in the regions of Maule, Bio Bio and La Araucania; in the south of the region of Los Lagos, and in the Aysen region. Valuable information was obtained generating agroforestry alternatives, which were subsequently implemented in lands of small farmers; inan area of approximately 500 ha.

This document shows the management model applied, the results obtained and a proposal of an Agroforestry Program for its implementation in Chile.

Key words: Agroforestry, small owners

\section{INTRODUCCION}

Entre los años 2003 y 2008, el Instituto de Desarrollo Agropecuario (INDAP) y el Instituto Forestal (INFOR), aunaron esfuerzos tendientes a desarrollar modelos agroforestales, con el propósito que los pequeños productores silvoagropecuarios, usuarios de INDAP, tuvieran la opción de aplicarlos en sus unidades productivas (predio), de modo tal que el uso de los recursos naturales existentes en esas unidades, especialmente el suelo, fuesen utilizados de manera sustentable, de acuerdo a su potencialidad y limitaciones.

Como es sabido, los modelos agroforestales permiten la interacción del uso forestal, ganadero y agrícola en un mismo sitio o unidad predial, en el cual se busca la optimización de la producción del suelo y, a su vez, aumentar la rentabilidad como sistema de uso integrado, considerando las sustentabilidad en el aprovechamiento de los recursos naturales presentes.

El sector agrícola y ganadero en la pequeña propiedad, presenta una serie de factores que influyen negativamente en su competitividad; entre ellos los principales son la escasa oferta y desarrollo tecnológico, un mercado interno sujeto a la competencia con mercados externos beneficiados con tratados internacionales, un escaso financiamiento y poder adquisitivo para implementar mejoras tecnológicas, y una pérdida de productividad por erosión de los suelos.

En zonas de secano, se suman a los anteriores factores la falta de riego, los suelos degradados, el escaso capital, su aislamiento geográfico y el reducido tamaño de la propiedad campesina. Estos factores negativos hacen prioritario que los propietarios aprovechen al máximo la productividad de sus sitios en forma sustentable, requieran un desarrollo integral de todos los sistemas operacionales del predio y que sean capaces de balancear a largo plazo los aspectos sociales, económicos y ambientales de la agricultura.

Para alcanzar este objetivo es necesario desarrollar nuevas alternativas de fuentes de ingresos para que los productores puedan mantenerse trabajando la tierra, se evite la migración y abandono de las tierras y se haga posible, que las comunidades rurales 
puedan sustentarse. Para esto es necesario utilizar innovaciones tecnológicas que permitan contrarrestar la acción perjudicial de los principales factores limitantes, como son el suelo, agua, temperatura, viento, los cuales pueden actuar negativamente sobre la pradera y otros cultivos, los árboles y los animales.

De acuerdo a las metas fijadas por el Ministerio de Agricultura (2002), para ayudar al fortalecimiento, desarrollo y productividad de la Agricultura Familiar Campesina, entre otros aspectos se debe trabajar en la diversificación de la producción, forestación campesina, bonificación a la forestación y facilitar un mayor acceso a la tecnológica.

Sobre la base del diagnóstico anterior y de las metas del Ministerio de Agricultura definidas para el año 2002, INDAP e INFOR se concentraron en buscar alternativas de diversificación de la producción para los pequeños propietarios, que tornen más atractiva su actividad productiva, tomando en cuenta aspectos culturales, de rentabilidad, y sustentabilidad. Entre las posibilidades que toman en cuenta estos aspectos, se considera el uso de sistemas agroforestales o silvopastorales, que les ayuden a diversificar su producción, protejan el recurso suelo y agua, y reinserten al árbol en su medio cultural. Con un sector agrícola más diversificado, puede significar para los productores el tener mejores alternativas, seleccionar aquellas más rentables y sustentables, y que incluyan tecnologías, entre otras las agroforestales de última generación. Es por ello que INDAP e INFOR se unieron en la búsqueda de nuevas alternativas productivas, mejores capacidades tecnológicas, y de transferencia de conocimientos que permitan en conjunto dar soluciones innovadoras al quehacer productivo de los pequeños productores silvoagropecuarios.

El manejo agroforestal, en especial el uso silvopastoral, entendiéndose como aquel manejo que combina los usos ganadero- forestal en un mismo sitio, o en una unidad predial, con el objetivo de aumentar la productividad del suelo, puede ser un mecanismo que posibilite un salto productivo-tecnológico a los pequeños propietarios. Además, este tipo de manejo, adaptado a la "ingeniería de restauración del medio ambiente", es una forma de aumentar la productividad de los sitios, diversificando la producción, aumentando las oportunidades de ingresos y disminuyendo la incertidumbre económica en los predios ganaderos y forestales. Los árboles, en su manejo silvícola, se deben manejar de forma que puedan producir madera de alta calidad y, además, provean protección al ganado, a la pradera y a los cultivos, de modo de aumentar la productividad del sistema como un todo.

Para desarrollar este tipo de sistemas de manejo integrado, se requiere adecuar y perfeccionar las capacidades tecnológicas existentes y buscar los mecanismos más adecuados de asociación tecnológica y empresarial. La oferta de conocimiento científico y empírico es suficiente para que comiencen a generarse cambios en la modalidad de las actividades agropecuarias y forestales. No obstante, aunque existen antecedentes y experiencias que se pueden replicar y transferir, aún es necesario implementar investigación y desarrollo específico en este tipo de manejo.

En su momento, se vio que la modificación del DL № 701 ocurrida en 1998, era una oportunidad que hacía más factible este tipo de producción mixta o integrada, en atención a la incorporación en el nuevo DL.701 de 1998 de la bonificación para cortinas cortavientos, 
y a densidades bajas de forestación, pensadas justamente para sistemas silvopastorales. Además, se consideraron los incentivos legales existentes a la recuperación de suelos degradados, que pueden ayudar a la recuperación de praderas sobreexplotadas y/o degradadas.

Por último, además de los beneficios productivos que tienen estos sistemas silvopastorales, hay otros de carácter ambientales, entre los cuales se pueden mencionar:

- Agua

Los árboles reducen la velocidad de las gotas de lluvia y permiten una mayor percolación en el suelo, y Las raíces ayudan a filtrar contaminantes de las aguas de escorrentía y aguas subterráneas.

- $\quad$ Aire

Los árboles reducen los olores y los polvos en las áreas donde se concentran los animales, también mitigan los efectos del cambio climático, al ser los árboles un sumidero de $\mathrm{CO}_{2}$.

- Suelo

El follaje de los árboles reduce la velocidad de las gotas de lluvia previniendo la erosión y ayudando a infiltrar el agua en el suelo, las raíces ayudan a retener el suelo.

- Vida Silvestre

Los sistemas que integran árboles y praderas proveen un hábitat diverso, refugio y protección para muchas especies animales terrestres. Los peces y otros animales acuáticos se benefician del control de la erosión y filtración de potenciales contaminantes.

- Plantas

Los árboles en un ambiente agrícola, proveen mayor diversidad, fortaleciendo al ecosistema, haciéndolo más saludable que sectores donde predominan los monocultivos.

- Humanos

Los árboles crean un paisaje estéticamente más agradable, proveen una fuente de ingresos y actividades económicas.

Sobre la base de lo anterior, los sistemas agroforestales, desarrollados a partir de la alianza INDAP - INFOR (2003 - 2008), pueden ser una alternativa de solución para 
aquellos propietarios que viven de rubros tradicionales (trigo, leguminosas y ganadería extensiva), en terrenos degradados o en vías de degradación, y en un constante procesos de migración hacia centros poblados por falta de mejores expectativas. A continuación, se muestra una reseña de lo que significó este trabajo interinstitucional.

\section{OBJETIVOS}

Diseñar, implementar y transferir modelos agroforestales que promuevan un desarrollo sustentable de la agricultura campesina, entre las regiones de Coquimbo y Aysén.

\section{METODOLOGIA}

La metodología empleada para la obtención del objetivo, tomó en cuenta las condiciones propias de la actividad agrícola de los pequeños productores silvoagropecuarios, es decir, rentabilidad del negocio (influido principalmente por precios), mercado (accesibilidad), tecnología (escasa), a lo que se agregan otras variables, tales como, clima, suelo, atomización de la propiedad y regularización de títulos de dominio.

La base de la metodología, consideró un trabajo participativo entre las instituciones (INDAP e INFOR) con los pequeños productores silvoagropecuarios, y se organizó en cuatro actividades secuenciales y dependientes.

El desarrollo metodológico del proyecto se orientó a generar un desarrollo tecnológico asociado a una combinación de uso forestal y agropecuario, que implicara un aumento de la producción ganadera o agrícola, por la influencia beneficiosa que otorga el árbol con medidas de protección ambiental, especialmente a suelos y aguas, y a su vez entregara una posibilidad de diversificación productiva con un nuevo negocio como es el forestal. Es decir, que en un mismo sitio o predio, se generen dos o más productos en vez de uno, disminuyendo el riesgo ante cambios de mercado o climáticos, lo que impulsará un desarrollo económico más sostenible y amigable con el medio ambiente, para los pequeños propietarios locales.

La metodología definió 4 etapas:

\section{Etapa I: Diseño de Modelos Agroforestales}

En esta etapa las actividades o acciones se dirigieron a la obtención de:

Recopilación y Sistematización de información científica y empírica (nacional e internacional).

Caracterización de Tipologías Productivas por Distritos Agroclimáticos de las unidades prediales. 
Análisis de los instrumentos de fomento e incentivos nacionales.

Realización de visitas tecnológicas por parte del equipo de investigadores a diferentes Unidades Experimentales.

Diseño y Empaquetamiento de Modelos Agroforestales.

Difusión de los resultados.

\section{Etapa II: Implementación de Módulos Agroforestales de Investigación y Demostrativos}

Luego del diseño y preparación de los paquetes tecnológicos agroforestales definidos por la Etapa I, se seleccionaron aquellos con mayor perspectiva de desarrollo y adopción por la agricultura campesina, validados en talleres participativos, para la implementación de módulos experimentales que serán evaluados y mejorados constantemente, como así también los módulos demostrativos que permitan su utilización en actividades de transferencia.

El diseño y magnitud de los módulos fue propuesto y acordado entre INDAP e INFOR luego del término de la Etapa I.

\section{Etapa III. Evaluación y Validación de Módulos y Preparación de Paquetes Tecnológicos}

En esta Etapa se evaluaron los módulos implementados en la Etapa anterior, para su validación y se preparo la Versión 2.0 de los paquetes tecnológicos agroforestales.

\section{Etapa IV. Divulgación y Masificación de los Modelos Agroforestales}

Con la Versión 2.0. de Modelos Agroforestales se fortalecerá la etapa de masificación de estos modelos, insertándolos en los programas de transferencia tecnológica del sector silvoagropecuario del Ministerio de Agricultura.

\section{RESULTADOS Y PRODUCTOS} productos:

Durante el desarrollo del proyecto se registraron los siguientes resultados $y / 0$

\section{Visitas Tecnológicas}

Se realizaron visitas a unidades experimentales y demostrativas, en la región del Maule (Talca, Linares, Cauquenes) y la región e Aysén (Provincias de Coyhaique y Capitán Prat, y en Cochrane), que tuvieran como objetivo la implementación de sistemas productivos agroforestales y de recuperación de suelos degradados. Estas unidades fueron establecidas por diversas instituciones (INFOR, CONAF, 
Prodecop-secano, U. Austral).

En la región de Maule se visitaron 7 unidades, en tanto, en la de Aysén fueron 4 unidades visitadas.

\section{Eventos de Capacitación Difusión}

a. Cursos de Agroforestería para profesionales técnicos de INDAP y Operadores

Entre las regiones de Maule y Aysén, se realizaron 14 cursos, con asistencia de 296 personas.

b. Talleres de Trabajo Agroforestal para Profesionales de INDAP

Se realizaron talleres en las regiones de Maule y La Araucanía, uno en cada región, con asistencia de 25 personas en total.

c. Días de Campo

En las regiones Maule, Bio Bio y Aysén, se visitaron unidades demostrativas, con presencia de profesionales de INDAP, CONAF, INIA, INFOR y agricultores. En total fueron 14 días de campo, con participación de aproximadamente 150 personas.

d. Charlas Divulgativas y Técnicas

Se realizaron 20 charlas de este tipo, en las regiones del Bio Bio, La Araucanía y Los Lagos, con presencia de agricultores y profesionales de INDAP, en total 238 personas.

e. Seminarios de Agroforesteria y Diversificación Forestal

Se realizaron en la región de Aysén (1 en Coyhaique), y en la región de La Araucanía (1 en Los Sauces), ambos de una duración de 2 días.

f. Apoyo a Operadores y Propietarios para la implementación de Modelos Agroforestales.

Período 2005-2006: Se brindó apoyo directo a operadores en la captación de 47 agricultores interesados en establecer sistemas agroforestales, en las regiones del Bio Bio y Aysén, de los cuales 13 hicieron presentaciones de Estudios Técnicos de Calificación, con fines silvopastorales, cortinas corta viento y recuperación de suelos degradados.

Período 2006-2007: Se establecieron 181,4 ha con modelos agroforestales, en las regiones del Maule, La Araucanía y Aysén, con modelos silvopastoral 
y cortinas cortaviento.

Período 2007-2008: Se establecieron 256,86 ha de sistemas agroforestales, en las regiones de Maule (49,6 ha), Bio Bio (22,5 ha), La Araucania (71,52 ha) y Los Lagos (113,24 ha), con 53 agricultores beneficiados.

g. Instrumentos de Difusión

Se confeccionaron e imprimieron 6 cartillas de divulgativas, que contienen material técnico.

- $\quad$ Cartilla Agroforestal № 1: Modelos Agroforestales

- $\quad$ Cartilla Agroforestal № 2: Sistemas Silvopatorales

- $\quad$ Cartilla Agroforestal № 3: Sistemas Agrosilvícolas

- Cartilla Agroforestal № 4: Beneficios Ambientales de la Agroforestería

- $\quad$ Cartilla Agroforestal № 5: Cortinas Cortaviento

- Cartilla Agroforestal № 6: Ordenación Predial y Agroforestería

\section{Instalación Unidades Demostrativas para Demostración del Método}

- Unidad Agroforestal de Los Álamos (Cauquenes, Maule)

- $\quad$ Unidad Recuperación de Riberas (Hualqui, Bio Bio)

- Unidad Agroforestal de Portezuelo (Portezuelo, Bio Bio)

- Unidad Agroforestal de Santa Julia (Collipulli, La Araucanía)

- Unidad Agroforestal de Amargo (Collipulli, La Araucania)

- Unidad Agroforestal de Fresia (Fresia, Los Lagos)

- Unidad Agroforestal San Gabriel (Coyhaique, Aysén)

\section{Creación y Mantención de Red Agroforestal Nacional (RAN)}

Se crea una página WEB, www.redagroforestal.cl, donde se vacía toda la información que se genera en el proyecto. Llegó a tener la inscripción de alrededor de 200 personas y es consultada en el ámbito nacional e internacional. 


\section{ANALISIS Y DISCUSION}

Durante el período de desarrollo del proyecto se presentaron diversas dificultades que se señalan a continuación, como asimismo, las soluciones propuestas.

1. Falta de interés por parte de los operadores privados para participar en el establecimiento de propuestas agroforestales, debido a baja perspectiva económica al tener que reducir la densidad en el establecimiento del componente forestal de acuerdo a tabla de costos establecidas en el DL.701, y complicación en la operatividad de los sistemas.

Solución propuesta:

Dado que efectivamente se recibe un menor valor al establecer densidades forestales bajas, y observándose el interés de los agricultores por su aplicación, se propone establecer un incentivo para su establecimiento. Este puede ser vía asistencia técnica, otorgándoseles un bono por plan de manejo, o mediante un bono en el establecimiento de hectáreas agroforestales, lo cual puede ser pagado por hectárea establecida.

2. Escaso conocimiento y valoración por parte de los productores respecto de sistemas integrados de producción agroforestal (mantención del sistema).

Solución propuesta:

Intensificar la difusión de estas propuestas agroforestales a través de instrumentos de difusión (cartillas, trípticos, y otros), charlas, días de campo y similares. También se propone que exista una mayor difusión e instrucción por parte de las autoridades de INDAP a las regiones y áreas, indicándose que esta iniciativa es un compromiso de INDAP para con los agricultores.

3. Se requiere un mayor conocimiento por parte de las instituciones que manejan los mecanismos de fomento (compatibilidad de instrumentos). En algunos casos existe disparidad de criterios entre regiones y áreas, y falta de conocimiento de las propuestas.

Solución propuesta:

Se requiere tener una mayor conexión y trabajo de conjunto con las áreas de INDAP y sus profesionales, para que se tenga un mayor conocimiento de este Programa Agroforestal, sus propuestas y la aplicación del SIRSD. Lo mismo se requiere hacer con CONAF en las regiones, en la aplicación del DL.701. Se propone establecer una mejor comunicación y difusión de estas alternativas dentro de INDAP y CONAF. Además se recomienda realizar talleres de trabajo con las regiones.

4. Se requiere una mayor uniformidad de criterios de aprobación y la operatividad y 
diseño de los sistemas agroforestales a presentar de acuerdo a los instrumentos de fomento (otras posibilidades de diseño).

Solución propuesta:

Establecer talleres de trabajo conjuntos con INDAP y CONAF para uniformar criterios y buscar soluciones.

5. Opción de uso de instrumentos de apoyo, como PDI y SAT, para compatibilizar con DL.701 y SIRSD.

Solución Propuesta:

Estudiar la aplicación de estas propuestas en conjunto con SIRSD y DL.701, y realizar casos pilotos en regiones.

6. Mejorar la capacidad técnica para la correcta aplicación de los sistemas agroforestales propuestos, de parte de operadores (correcta relación de sistemas productivos agroforestales/condición de sitio).

Solución propuesta:

Continuar con los cursos y actividades de transferencia hacia operadores de los instrumentos de fomento, y seguimientos de sus acciones. A su vez se requiere fortalecer la actividad de apoyo hacia los operadores en terreno.

\section{CONCLUSIONES}

Luego de terminado el proyecto, se puede concluir lo siguiente:

El uso de modelos agroforestales es factible en un manejo predial de los pequeños productores silvoagropecuarios.

La selección y combinación de los componentes forestal - agrícola - pecuario debe hacerse en relación a las potencialidades y condiciones del sitio, y a las necesidades del propietario.

Satisfecha las necesidades del propietario, en cuanto a lograr un consenso con el modelo a aplicar en la propiedad, es necesario obtener un compromiso de este, que apunte a las actividades de mantención del sistema.

Es necesario profundizar las acciones de capacitación y difusión de estos sistemas de producción múltiple, entre los productores, operadores e instituciones estatales.

Resulta necesario mantener la alianza entre INDAP e INFOR, con el propósito 
de replicar lo que se ha realizado durante los 6 años del proyecto (unidades, cursos, difusión, apoyos a interesados), además, de hacer el seguimiento a las unidades ya establecidas, y así obtener antecedentes que permitan ir mejorando las propuestas iniciales.

Del recorrido territorial que abarcó el proyecto, se puede señalar que en muchas situaciones analizadas, los sistemas agroforestales son una solución viable para los pequeños productores silvoagropecuarios. 


\section{REGLAMENTO DE PUBLICACION}

CIENCIA E INVESTIGACION FORESTAL es una publicación técnica, cientííica, arbitrada y seriada del Instituto Forestal de Chile, en la que se publica trabajos originales e inéditos, con resultados de investigaciones o avances de estas, realizados por sus propios investigadores y por profesionales del sector, del país o del extranjero, que estén interesados en difundir sus experiencias en áreas relativas a las múltiples funciones de los bosques, en los aspectos económicos, sociales y ambientales. Consta de un volumen por año el que a partir del año 2007 está compuesto por tres números (abril, agosto y diciembre) y ocasionalmente números especiales.

La publicación cuenta con un Consejo Editor institucional que revisa en primera instancia los trabajos presentados y está facultado para aceptarlos, rechazarlos o solicitar modificaciones a los autores. Dispone además de un selecto grupo de profesionales externos y de diversos países, de variadas especialidades, que conforma el Comité Editor. De acuerdo al tema de cada trabajo, estos son enviados por el Editor a al menos tres miembros del Comité Editor para su calificación especializada. Los autores no son informados sobre quienes arbitran los trabajos.

La revista consta de dos secciones; Artículos Técnicos y Apuntes, puede incluir además artículos de actualidad sectorial en temas seleccionados por el Consejo Editor o el Editor.

- Artículos: Trabajos que contribuyen a ampliar el conocimiento científico o tecnológico, como resultado de investigaciones que han seguido un método científico.

- Apuntes: Comentarios o análisis de temas particulares, que presenten enfoques metodológicos novedosos, representen avances de investigación, informen sobre reuniones técnicas o programas de trabajo y otras actividades de interés dentro del sector forestal o de disciplinas relacionadas. Los apuntes pueden ser también notas bibliográficas que informan sobre publicaciones recientes, en el país o en el exterior, comentando su contenido e interés para el sector, en términos de desarrollo científico y tecnológico o como información básica para la planificación y toma de decisiones.

\section{ESTRUCTURA DE LOS TRABAJOS}

\section{Artículos}

Los trabajos presentados para esta sección deberán contener Resumen, Summary, Introducción, Objetivos, Material y Método, Resultados, Discusión y Conclusiones, Reconocimientos (optativo) y Referencias. En casos muy justificados Apéndices y Anexos. 
Título: El título del trabajo debe ser representativo del efectivo contenido del artículo y debe ser construido con el mínimo de palabras.

Resumen: Breve descripción de los objetivos, de la metodología y de los principales resultados y conclusiones. Su extensión máxima es de una página y al final debe incluir al menos tres palabras clave que faciliten la clasificación bibliográfica del artículo. No debe incluir referencias, cuadros ni figuras. Bajo el título se identificará los autores y a pie de página su institución y dirección. El Summary es evidentemente la versión en inglés del Resumen.

Introducción: Como lo dice el título, este punto está destinado a introducir el tema, describir lo que se quiere resolver o aquello en que se necesita avanzar en materia de información, proporcionar antecedentes generales necesarios para el desarrollo o compresión del trabajo, revisar información bibliográfica y avances previos, situar el trabajo dentro de un programa más amplio si es el caso, y otros aspectos pertinentes. Los Antecedentes Generales y la Revisión de Bibliografía pueden en ciertos casos requerir especial atención y mayor extensión, si así fuese, en forma excepcional puede ser reducida la Introducción a lo esencial e incluir estos puntos separadamente.

Objetivos: Breve enunciado de los fines generales del artículo o de la línea de investigación a que corresponda y definición de los objetivos específicos del artículo en particular.

Material y Método: Descripción clara de la metodología aplicada y, cuando corresponda, de los materiales empleados en las investigaciones o estudios que dan origen al trabajo. Si la metodología no es original se deberá citar claramente la fuente de información. Este punto puede incluir Cuadros y Figuras, siempre y cuando su información no resulte repetida con la entregada en texto.

Resultados: Punto reservado para todos los resultados obtenidos, estadísticamente respaldados cuando corresponda, y asociados directamente a los objetivos específicos antes enunciados. Puede incluir Cuadros y Figuras indispensables para la presentación de los resultados 0 para facilitar su comprensión, igual requisito deben cumplir los comentarios que aquí se pueda incluir.

Discusión y Conclusiones: Análisis e interpretación de los resultados obtenidos, sus limitaciones y su posible trascendencia. Relación con la 
bibliografía revisada y citada. Las conclusiones destacan lo más valioso de los resultados y pueden plantear necesidades consecuentes de mayor investigación o estudio o la continuación lógica de la línea de trabajo.

Reconocimientos: Punto optativo, donde el autor si lo considera necesario puede dar los créditos correspondientes a instituciones o personas que han colaborado en el desarrollo del trabajo o en su financiamiento. Obviamente se trata de un punto de muy reducida extensión.

Referencias: Identificación de todas las fuentes citadas en el documento, no debe incluir referencias que no han sido citadas en texto y deben aparecer todas aquellas citadas en éste.

Apéndices y Anexos: Deben ser incluidos sólo si son indispensables para la comprensión del trabajo y su incorporación se justifica para reducir el texto. Es preciso recordar que los Apéndices contienen información o trabajo original del autor, en tanto que los Anexos contienen información complementaria que no es de elaboración propia.

\section{Apuntes}

Los trabajos presentados para esta sección tienen en principio la misma estructura descrita para los artículos, pero en este caso, según el tema, grado de avance de la investigación o actividad que los motiva, se puede adoptar una estructura más simple, obviando los puntos que resulten innecesarios.

\section{PRESENTACION DE LOS TRABAJOS}

La Revista acepta trabajos en español y ocasionalmente en inglés o portugués, redactadas en lenguaje universal, que pueda ser entendido no sólo por especialistas, de modo de cumplir su objetivo de transferencia de conocimientos y difusión al sector forestal en general. No se acepta redacción en primera persona.

Formato tamaño carta $(21,6 \times 27,9 \mathrm{~cm})$, márgenes $2,5 \mathrm{~cm}$ en todas direcciones, espacio simple y un espacio libre entre párrafos. Letra Arial 10. Un tab (8 espacios) al inicio de cada párrafo. No numerar páginas. Extensión máxima trabajos 25 carillas para artículos y 15 para Apuntes. Justificación ambos lados.

Primera página incluye título en mayúsculas, negrita, centrado, letra Arial 12, una línea, eventualmente dos como máximo. Dos espacios bajo éste: Autor (es), minúsculas, letra 10 y llamado a pie de página indicando Institución, país y correo electrónico en letra Arial 8. Dos espacios más abajo el Resumen y, si el espacio resulta suficiente, el Summary. Si no lo es, página siguiente igual que anterior, el Summary. 
En el caso de los Apuntes, en su primera página arriba tendrán el título del trabajo en mayúscula, negrita, letra 12 y autor (es), institución, país y correo, letra 10, normal minúsculas, bajo una línea horizontal, justificado a ambos lados, y bajo esto otra línea horizontal. Ej:

\section{EL MANEJO FORESTAL SOSTENIBLE COMO MOTOR DE EMPRENDIMIENTO DEL MUNDO RURAL: LA EXPERIENCIA}

EN CHILE. Víctor Vargas Rojas. Instituto Forestal. Ingeniero Forestal. Mg. Economía de Recursos Naturales y del Medio Ambiente. vvargas@infor.cl

Título puntos principales (Resumen, Summary, Introducción, Objetivos, etc) en mayúsculas, negrita, letra 10, margen izquierdo. Sólo para Introducción usar página nueva, resto puntos principales seguidos, separando con un espacio antes y después de cada uno. Títulos secundarios en negrita, minúsculas, margen izquierdo. Títulos de tercer orden minúsculas margen izquierdo. Si fuesen necesarios títulos de cuarto orden, usar minúsculas, un tab (7 espacios) y anteponer un guión y un espacio. Entre sub títulos y párrafos precedente y siguiente un espacio libre. En sub títulos con más de una palabra usar primera letra de palabras principales en mayúscula. No numerar puntos principales ni sub títulos.

Nombres de especies vegetales o animales: Vulgar o vernáculo en minúsculas toda la palabra, seguido de nombre en latín o científico entre paréntesis la primera vez que es mencionada la especie en el texto, en cursiva (no negrita), minúsculas y primera letra del género en mayúsculas. Ej. pino o pino radiata (Pinus radiata).

Citas de referencias bibliográficas: Sistema Autor, año. Ejemplo en citas en texto; De acuerdo a Rodríguez (1995) el comportamiento de...., o el comportamiento de... (Rodríguez, 1995). Si son dos autores; De acuerdo a Prado y Barros (1990) el comportamiento de ..., o el comportamiento de ... (Prado y Barros, 1990). Si son más de dos autores; De acuerdo a Mendoza et al. (1990), o el comportamiento ... (Mendoza et al., 1990).

En el punto Referencias deben aparecer en orden alfabético por la inicial del apellido del primer autor, letra 8, todas las referencia citadas en texto y sólo estas. En este punto la identificación de la referencia debe ser completa: Autor (es), año. En negrita, minúsculas, primeras letras de palabras en mayúsculas y todos los autores en el orden que aparecen en la publicación, aquí no se usa et al. A continuación, en minúscula y letra 8 , primeras letras de palabras principales en mayúscula, título completo y exacto de la publicación, incluyendo institución, editorial y otras informaciones cuando corresponda. Margen izquierdo con justificación ambos lados. Ejemplo:

En texto: (Yudelevich et al., 1967) o Yudelevich et al. (1967) señalaron ...

En referencias: 
Yudelevich, Moisés; Brown, Charles y Elgueta, Hernán, 1967. Clasificación Preliminar del Bosque Nativo de Chile. Instituto Forestal. Informe Técnico № 27. Santiago, Chile.

Expresiones en Latín, como et al.; a priori y otras, así como palabras en otros idiomas como stock, marketing, cluster, stakeholders, commodity y otras, que son de frecuente uso, deben ser escritas en letra cursiva.

Cuadros y Figuras: Numeración correlativa: No deben repetir información dada en texto. Sólo se aceptan cuadros y figuras, no así tablas, gráficos, fotos u otras denominaciones. Toda forma tabulada de mostrar información se presentará como cuadro y al hacer mención en texto (Cuadro № 1). Gráficos, fotos y similares serán presentadas como figuras y al ser mencionadas en texto (Figura № 1). En ambos casos aparecerán enmarcados en línea simple y centrados en la página. En lo posible su contenido escrito, si lo hay, debe ser equivalente a la letra Arial 10 u 8 y el tamaño del cuadro o figura proporcionado al tamaño de la página. Cuadros deben ser titulados como Cuadro № , minúsculas, letra 8 , negrita centrado en la parte superior de estos, debajo en mayúsculas, negritas letra 8 y centrado el título (una línea en lo posible). Las figuras en tanto serán tituladas como Figura № , minúscula, letra 8, negrita, centrado, en la parte inferior de estas, y debajo en mayúsculas, letra 8, negrita, centrado, el título (una línea en lo posible). Si la diagramación y espacios lo requieren es posible recurrir a letra Arial narrow. Cuando la información proporcionada por estos medios no es original, bajo el marco debe aparecer entre paréntesis y letra 8 la fuente o cita que aparecerá también en referencias. Si hay símbolos u otros elementos que requieren explicación, se puede proceder de igual forma que con la fuente.

Se aceptan fotos en blanco y negro y en colores, siempre que reúnan las características de calidad y resolución que permitan su impresión.

Abreviaturas, magnitudes y unidades deben estar atenidas a la Norma NCh 30 del Instituto Nacional de Normalización (INN). Se empleará en todo caso el sistema métrico decimal. Al respecto es conveniente recordar que la unidades se abrevian en minúsculas, sin punto, con la excepción de litro (L) y de aquellas que provienen de apellidos de personas como grados Celsius $\left({ }^{\circ} \mathrm{C}\right)$. Algunas unidades de uso muy frecuente: metro, que debe ser abreviado $\mathbf{m}$, metro cúbico $\mathbf{m}^{3}$, metro ruma $\mathbf{m r}$; o hectáreas ha.

Llamados a pie de página: Cuando estos son necesarios, serán numerados en forma correlativa para cada página, no de 1 a $n$ a lo largo del trabajo. Aparecerán al pie en letra 8. No usar este recurso para citas bibliográficas, que deben aparecer como se indica en Referencias.

Archivos protegidos, "sólo lectura" o PDF serán rechazados de inmediato porque no es posible editarlos. La Revista se reserva el derecho de efectuar todas las modificaciones de carácter formal que el Comité Editor o el Editor estimen necesarias o convenientes, sin consulta al autor. Modificaciones en el contenido evidentemente son consultadas por el Editor al autor, si no hay acuerdo se recurre nuevamente al Consejo Editor o los miembros de este que han participado en el arbitraje o calificación del trabajo. 


\section{ENVIO DE TRABAJOS}

Procedimiento electrónico. En general bastará enviar archivo Word, abierto al Editor sbarros@infor.gob.cl

Cuadros y figuras ubicadas en su lugar en el texto, no en forma separada. El Editor podrá en algunos casos solicitar al autor algún material complementario en lo referente a cuadros y figuras (archivos Excel, imágenes, figuras, fotos, por ejemplo).

El autor deberá indicar si propone el trabajo para Artículo o Apunte y asegurarse de recibir confirmación de la recepción conforme del trabajo por parte del Editor.

Respecto del peso de los archivos, tener presente que $1 \mathrm{Mb}$ es normalmente el límite razonable para los adjuntos por correo electrónico. No olvidar que las imágenes son pesadas, por lo que siempre al ser pegadas en texto Word es conveniente recurrir al pegado de imágenes como JPEG o de planillas Excel como Metarchivo Mejorado.

En un plazo de 30 días desde la recepción de un trabajo el Editor informará al autor principal sobre su aceptación (o rechazo) en primera instancia e indicará (condicionado al arbitraje del Comité Editor) el Volumen y Número en que el trabajo sería incluido. Posteriormente enviará a Comité Editor y en un plazo no mayor a 3 meses estará sancionada la situación del trabajo propuesto. Si se mantiene la información dada por el Editor originalmente, el trabajo es aceptado como fue propuesto (Articulo o Apunte) y no hay observaciones de fondo, el trabajo es editado y pasa a publicación cuando y como se informó al inicio. Si no es así, el autor principal será informado sobre cualquier objeción, observación o variación, en un plazo total no superior a 4 meses. 


\section{CIENCIA E INVESTIGACION FORESTAL}

PRODUCTIVIDAD ANIMAL, EN UN SISTEMA SILVOPASTORAL CON LA ESPECIE Pinus contorta DOUG. EX. LOUD., EN RELACION A UN MANEJO GANADERO SIN ÁRBOLES, EN LA REGIÓN DE AYSÉN, CHILE. Álvaro Sotomayor, Osvaldo Teuber, Iván Moya y Patricio Almonacid, Chile.

COMPORTAMIENTO TÉRMICO Y EFICIENCIA ENERGÉTICA DE VIVIENDAS SOCIALES DE MADERA CON MUROS VENTILADOS. Marcelo González Retamal y Gonzalo Hernández Careaga, Chile.

COMPORTAMIENTO EN TERRENO DE PLANTAS DE QUILLAY (Quillaja saponaria Mol.), PRODUCIDAS EN DIFERENTES VOLÚMENES DE CONTENEDOR. Iván Quiroz, Andrés Hernández, Edison García, Marta Gonzalez y Hernán Soto, Chile.

HACIA UN SISTEMA DE USO SILVOPASTORAL CON ÁRBOL NATIVO. Laura Sánchez-Jardón, España; Alejandro del Pozo, Chile; Belén Acosta, España; Miguel Ángel Casado, España; Carlos Ovalle, Chile; Felipe Elizalde, Chile; Christian Hepp, Chile; José Manuel de Miguel, España.

ADAPTACIÓN DE ESPECIES DE BAMBÚ DE CLIMA TEMPLADO EN CHILE. Marlene González, Jorge Campos y Jorge Cabrera, Chile.

SISTEMAS SILVOPASTORILES EN BOSQUES DE Nothofagus antarctica REVISIÓN DEL CONOCIMIENTO ACTUAL EN PATAGONIA SUR, ARGENTINA. Pablo Peri, Argentina.

CONSERVATION BUFFERS. DESIGN GUIDELINES FOR BUFFERS, CORRIDORS, AND GREENWAYS. Richard Straight and Gary Bentrup, United States.

\section{APUNTES}

LA AGROFORESTERIA UNA ALTERNATIVA PARA LA AGRICULTURA FAMILIAR CAMPESINA. Renato

Coda Salgado y Alvaro Sotomayor Garreton, Chile.

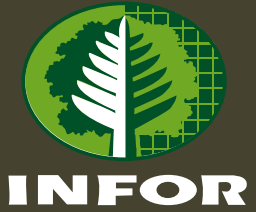

